\title{
Near-infrared spectroscopy: What we know and what we need to know-A systematic review of the congenital heart disease literature
}

\author{
Jennifer C. Hirsch, MD, ${ }^{a}$ John R. Charpie, MD, PhD, ${ }^{b}$ Richard G. Ohye, MD, ${ }^{a}$ and James G. Gurney, $\mathrm{PhD}^{\mathrm{c}}$
}

\begin{abstract}
Objectives: Neurologic dysfunction is a problem in patients with congenital heart disease. Near-infrared spectroscopy may provide a real-time window into cerebral oxygenation. Enthusiasm for near-infrared spectroscopy has increased hopes of reducing neurologic dysfunction. However, potential gains need to be evaluated relative to cost before routine implementation. Responding to data in ways that seem intuitively beneficial can be risky when the long-term impact is unknown. Thus, we performed a systematic review of the literature on near-infrared spectroscopy in congenital heart disease.
\end{abstract}

Methods: A literature search from 1950 to April 2007 for near-infrared spectroscopy in congenital heart disease was undertaken. We identified 54 manuscripts and 13 reviews.

Results: There were 47 case series, 4 randomized trials, and 3 retrospective studies. Two studies had postdischarge follow-up, one incorporating neurologic testing. Neither of these studies demonstrated a benefit. One retrospective study, which included near-infrared spectroscopy and other intraoperative measures of cerebral perfusion, demonstrated a decrease in neurologic dysfunction using this combination of monitors. Three small studies were able to correlate near-infrared spectroscopy with other clinical and radiologic findings.

Conclusions: Many centers, and even entire countries, have adopted near-infrared spectroscopy as standard of care. The available data suggest that multimodality monitoring, including near-infrared spectroscopy, may be a useful adjunct. The current literature on the use of near-infrared spectroscopy alone, however, does not demonstrate improvement in neurologic outcome. The data correlating near-infrared spectroscopy findings with indirect measures of neurologic outcome or mortality are limited. Although near-infrared spectroscopy has promise for measuring regional tissue oxygen saturation, the lack of data demonstrating improved outcomes limits the support for widespread implementation.

\section{Supplemental material is available online.}

Neurologic dysfunction is a significant problem in congenital heart disease (CHD). Historically, cardiac surgeons and cardiologists have had significant interest in acute clinical neurologic abnormalities such as stroke and seizure. With improved perioperative care, however, the prevalence of major acute neurologic abnormalities has decreased to $1 \%$ to $2 \%$ of open heart cases. ${ }^{1}$ Of growing concern are late neurodevelopmental and behavioral problems associated with pediatric cardiac surgery. ${ }^{2}$ These late neurologic impairments are compounded in children who require multiple

From the Department of Surgery, Section of Cardiac Surgery, Division of Pediatric Cardiovascular Surgery, ${ }^{a}$ the Department of Pediatrics, Section of Pediatric Cardiology, ${ }^{\mathrm{b}}$ and the Department of Pediatrics, Child Health Evaluation and Research Unit, ${ }^{\mathrm{c}}$ University of Michigan Medical School, Ann Arbor, Mich.

The project was supported by the Michigan Congenital Heart Outcomes Research and Discovery unit (M-CHORD) with intramural funds from the Department of Surgery, University of Michigan.

Received for publication Jan 9, 2008; revisions received May 5, 2008; accepted for publication Aug 2, 2008.

Address for reprints: Jennifer C. Hirsch, MD, 5144 Cardiovascular Center, Ann Arbor, MI 48109-5864 (E-mail: jhirsch@umich.edu).

J Thorac Cardiovasc Surg 2009;137:154-9

$0022-5223 / \$ 36.00$

Copyright (c) 2009 by The American Association for Thoracic Surgery

doi: $10.1016 /$ j.jtcvs. 2008.08 .005 operations. With increasing overall survival, the understanding of the impact of long-term neurologic sequelae on quality of life is crucial. Significant efforts from physicians and industry have been directed toward developing improved monitoring techniques for early detection of neurologic injury in hopes of averting or ameliorating subsequent complications. Current technologies include transcranial Doppler, electroencephalograms, bispectral index, biomarkers, and jugular bulb oximetry. Physician enthusiasm has increased for the use of near-infrared spectroscopy (NIRS) in the perioperative period in hopes of reducing neurologic dysfunction.

NIRS is based on the differential absorption of varying wavelengths of light by hemoglobin as it associates with oxygen. It provides a regional measurement of oxygen content in a localized tissue bed. The device can be used for both cerebral and somatic regional measurements. The value reported represents the amount of oxygen present within the tissue, including arterioles, capillaries, and venules. The measurement is venous weighted $(85 \%$ venous, $15 \%$ arterial). The purported value of cerebral NIRS is the ability to obtain noninvasive, real-time information on the cerebral oxygen content in the frontal cortex that reflects both oxygen delivery and consumption. This information may help guide interventions by the surgical team or intensive care physicians to maintain theoretically safe cerebral oxygenation levels. 


\section{Abbreviations and Acronyms \\ $\mathrm{CHD}=$ congenital heart disease \\ MRI = magnetic resonance imaging \\ NIRS $=$ near-infrared spectroscopy \\ $\mathrm{rScO}_{2}=$ regional cerebral oxygen saturation}

NIRS technology has been described in the adult and pediatric cardiac literature in multiple clinical settings, including the intensive care unit and operating room. As with any new technology, the potential clinical gains (and limitations) need to be critically evaluated before integration into routine patient care. Each additional monitoring device comes with an additional cost and with increasing patient care complexity. In addition, responding to data in ways that seem intuitively beneficial can be risky when the long- or even intermediate-term impact on clinical outcomes is unknown. Within this context, we conducted a systematic review of the scientific literature to examine the available evidence for the use of NIRS in the care of patients with CHD.

\section{METHODS}

\section{Eligibility Criteria}

Inclusion criteria for the literature search were limited to human studies, English language, and pediatric cardiac patients; all such manuscripts using NIRS in any area of pediatric cardiology and pediatric cardiac surgery were included. Editorials, case reports, and duplicates were excluded. We reviewed narrative reviews of the use of NIRS in pediatric cardiac patients to avoid publication bias and to highlight the key difference between systematic and narrative reviews. The content of the narrative reviews was not included, as is customary, in the formal systematic review as it does not represent a primary scientific manuscript. All references were evaluated from the manuscripts to confirm inclusion of all pertinent studies.

\section{Search Strategy}

We searched the English language literature about the use of NIRS in the pediatric cardiac population from 1950 to April 2007 with MEDLINE, PreMEDLINE, EMBASE, and Cochrane databases. The MEDLINE search was performed combining the key word search: near infrared spectroscopy, NIRS, or infrared spectroscopy. This list was combined with a keyword search including the following: pediatric cardiac surgery, CHD, pediatric, pediatric cardiology, intensive care, ICU, cardiopulmonary bypass, $C P B$, hypothermic circulatory arrest, or DHCA. The results of the MEDLINE search are outlined in Figure 1. We identified a total of 224 manuscripts and we reviewed all abstracts. Manuscripts were excluded on adult patients, noncardiac patients, non-English language, editorials, single case reports, and duplicates. After these exclusions, a total of 48 manuscripts remained with an additional 8 manuscripts identified from the references of the narrative reviews. Further, we evaluated all articles classified as narrative review articles involving the patient population of interest along with their references to confirm an exhaustive review of the scientific literature.

\section{Data Review and Analysis}

We created a standardized data retrieval form. A single reviewer (J.C.H.) extracted data from the manuscripts and assessed clinical study site, study design, patient population, sample size, mode of monitoring, NIRS device, primary and secondary outcomes, intervention if any, and follow-up. We subclassified manuscripts into general clinical sites for review and compilation (Figure 2). It was not possible to perform a meaningful meta-analysis with generation of a summary statistic owing to variation in end points, study design, monitoring device, and statistical analyses.

\section{RESULTS}

We identified 56 manuscripts that fit the eligibility criteria (Figure 1). We also identified and reviewed an additional 13 narrative review articles for comparative purposes. For simplicity of evaluation, we sorted the manuscripts by the clinical setting (Figure 2). Of the 13 review articles, 4 narrative reviews specifically focused on NIRS in the care of patients undergoing pediatric cardiac surgery. ${ }^{3-6}$ These review articles were not inclusive of all the potential clinical settings. The median number of manuscripts referenced within the review articles on NIRS and CHD patients was $8.5 .^{3-15}$

The primary research manuscripts evaluated 6 different devices: INVOS (Somanetics, Troy, Mich), NIRO (Hamamatsu Photonics, Hamamatsu City, Japan), NIMS (NIMS Inc, Philadelphia, Pa), Radiometer (Copenhagen, Denmark), PSA-3N (Biomedical Science, Kanazawa, Japan), and Inspectra Tissue Spectrometer (Hutchinson Technology, Hutchinson, Minn). Owing to the natural progression of device technology, one can observe multiple models of the INVOS and NIRO devices evaluated in the literature. Various devices use different terminology to refer to cerebral oxygen content (Table 1).

\section{Intraoperative Monitoring}

A total of 38 manuscripts involved the use of NIRS in the intraoperative setting. The manuscripts were subdivided into 8 categories for summative purposes (Figure 3). Table E1 shows the author, year of publication, study design, monitoring device, patient population, number of patients, primary end point, and results. The manuscripts include 31 case series, 4 randomized trials, and 3 retrospective studies. The median sample size was 20 (range, 9-250). Two of the 38 manuscripts (in fact, the only 2 of the 56 overall manuscripts) had planned follow-up after hospital discharge; these followups occurred at 3 months. ${ }^{16,17}$ One retrospective study assessed the role of an interventional algorithm on neurologic outcomes. ${ }^{18}$ They found that in patients with postoperative neurologic changes, more had noteworthy intraoperative cerebral perfusion changes (defined as a $50 \%$ decrease in cerebral blood flow by transcrianial Doppler, excessive electroencephalographic slowing, or a decrease in regional cerebral oxygen saturation $\left[\mathrm{rScO}_{2}\right]$ by NIRS of $>20 \%$ for 3 minutes) that were not intervened on with a predetermined algorithm $(P=.003) .^{18}$ Three manuscripts evaluated the association of NIRS findings with direct clinical outcomes. ${ }^{19-21}$ One retrospective study $(\mathrm{n}=34)$ demonstrated that patients who died after a single ventricle first-stage palliation had lower $\mathrm{rScO}_{2}$ at the end of the operation $(P=.01)$, but with no correlation to clinical neurologic abnormalities. ${ }^{22}$ Two case 


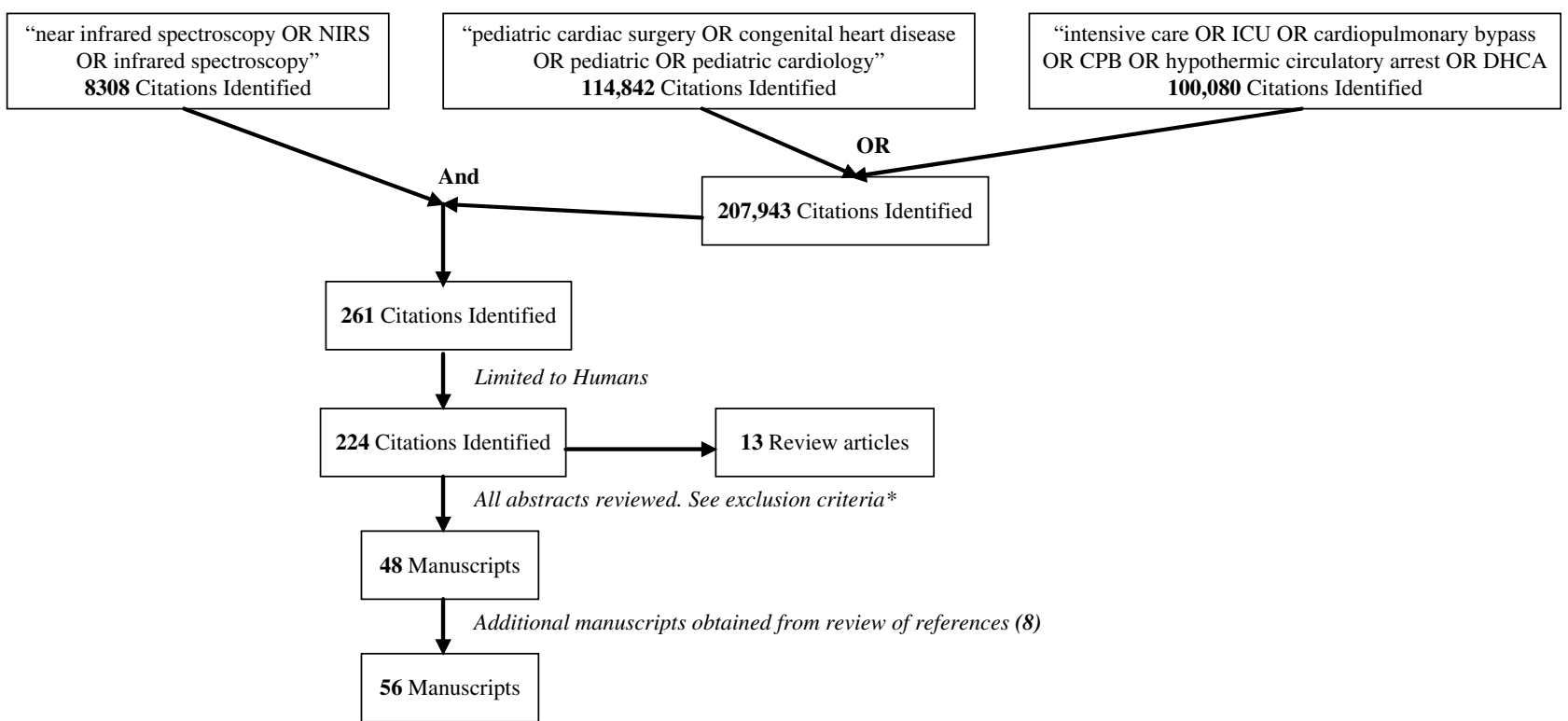

FIGURE 1. Search strategy and study selection for inclusion. *Exclusion criteria: adult patients, non-English, noncardiac patients, editorials, case reports, and duplicates.

series correlated intraoperative NIRS measurements with postoperative magnetic resonance imaging (MRI) findings. ${ }^{19,21}$ One $(\mathrm{n}=16)^{21}$ demonstrated that decreased $\mathrm{rScO}_{2}$ during aortic crossclamping in patients was associated with abnormal postoperative MRIs $(P=.08)$. The other $(\mathrm{n}=$ $22)^{19}$ found that prolonged low postoperative $\mathrm{rScO}_{2}$ less than $45 \%$ for more than 180 minutes was associated with either new or worsening lesions on postoperative MRI $(P=.029)$.

\section{Intensive Care Unit Monitoring}

Eleven manuscripts were identified that described the use of NIRS in the intensive care unit for patients with CHD. All of these manuscripts were case series, with a median sample size of 15 (range, 5-110). No studies contained neurologic follow-up assessments, nor did they correlate NIRS findings with clinical outcomes. Table E2 shows the author, year of publication, study design, monitoring device, patient popu-

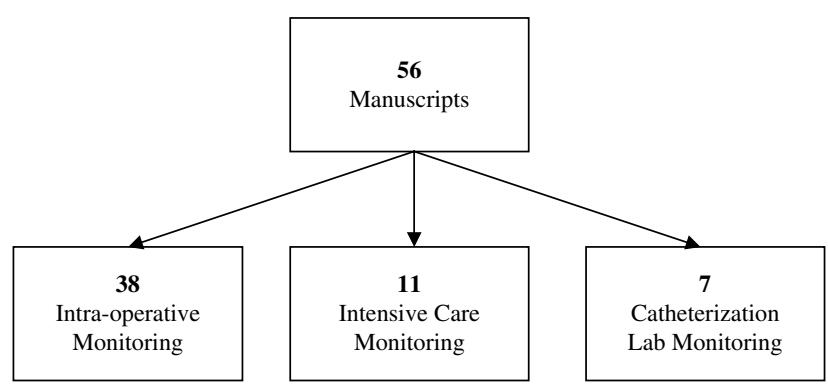

FIGURE 2. Classification of included manuscripts based on clinical application. lation, number of patients, primary end point, and results. Three studies focused on preoperative monitoring to define baseline values ${ }^{23}$ and the response to hypoxia ${ }^{24}$ and hypercarbia. ${ }^{25}$ Seven studies focused on postoperative intensive care monitoring. These studies sought to correlate NIRS measurements with somatic NIRS measurements, ${ }^{26,27}$ alterations in ventilator management, ${ }^{28,29}$ sildenafil use, ${ }^{30}$ and global measurements of systemic oxygenation. ${ }^{31,32}$ They identified correlations between $\mathrm{rScO}_{2}$ and various traditional hemodynamic parameters (mean and systemic arterial pressure, arterial saturation, and mixed venous saturation). One study incorporated NIRS monitoring for single ventricle patients after stage 1 palliation on temporary ventricular assist devices. That study demonstrated a significant decrease in $\mathrm{rScO}_{2}$ after the discontinuation of cardiopulmonary bypass. The decreased $\mathrm{rScO}_{2}$ did not normalize for 48 hours despite normalization of other standard measurements such as lactate and mean arterial pressure. ${ }^{33}$ The overarching findings in all of the studies were the presence of large interindividual variability and intraindividual temporal variability, which makes direct comparisons or determination of discrete safety measurements difficult.

\section{Cardiac Catheterization Laboratory}

Seven manuscripts were identified that described the use of NIRS for patients with CHD in the catheterization laboratory. All of these manuscripts were case series, with a median sample size of 29 (range, 11-98). None of these studies contained neurologic follow-up or correlated NIRS findings with clinical outcomes. Table E3 shows the author, year of publication, study design, monitoring device, patient 
TABLE 1. NIRS devices and monitoring terminology

\begin{tabular}{|c|c|c|}
\hline Device & Measurement & Abbreviation \\
\hline INVOS & Regional oxygen saturation (cerebral or somatic) & $\mathrm{rScO}_{2}$ or $\mathrm{rSO}_{2}$ \\
\hline NIRO & $\begin{array}{l}\text { Tissue oxygenation (oxyhemoglobin and deoxyhemoglobin), cellular } \\
\text { oxygenation based on the oxidized state of cytochrome } \mathrm{aa}_{3} \text { and the } \\
\text { tissue oxygenation index }\end{array}$ & oxyHgb, deoxyHgb, total $\mathrm{Hgb}, \mathrm{Cytaa}_{3}$, TOl \\
\hline NIMS & Regional cerebral oxygen saturation & $\mathrm{ScO}_{2}$ \\
\hline Radiometer & $\begin{array}{l}\text { Tissue oxygenation (oxyhemoglobin and deoxyhemoglobin), cellular } \\
\text { oxygenation based on the oxidized state of cytochrome } a_{3}\end{array}$ & $\mathrm{Hbo}_{2}, \mathrm{Hb}$, cyt $\mathrm{O}_{2}$ \\
\hline PSA-3N & Regional cerebral hemoglobin oxygen saturation & $\mathrm{SrO}_{2}$ \\
\hline Inspectra tissue spectrometer & Tissue saturation & $\mathrm{S}_{\mathrm{TO} 2}$ \\
\hline
\end{tabular}

population, number of patients, primary end point, and results. As with the studies in the intensive care unit, many studies attempted to correlate NIRS findings with standard measurements of global oxygenation. ${ }^{34-38}$ One study correlated alterations in regional and global saturation with alterations in ventilation. ${ }^{39}$ A second manuscript reported on the effect of balloon inflation during balloon dilation procedures in patients with and without intracardiac shunts. This study found that $\mathrm{rScO}_{2}$ decreases with balloon inflation in patients with intracardiac shunts and that the recovery time is directly related to inflation time. ${ }^{40}$ As with the studies in the intensive care unit, significant interindividual variability existed, making it difficult to compare patients.

\section{CONCLUSIONS}

Systematic reviews allow for a "pause" in the process of conducting research. They demonstrate, based on the available evidence, what we do know about a specific question. This information is then used to direct future research studies to clarify the areas of uncertainty. Systematic reviews follow a prospectively defined protocol to identify and appraise the relevant evidence. This is important in minimizing publication and information bias, which sets this methodology apart from traditional narrative reviews. Systematic reviews are limited by the quality of the original research being reviewed

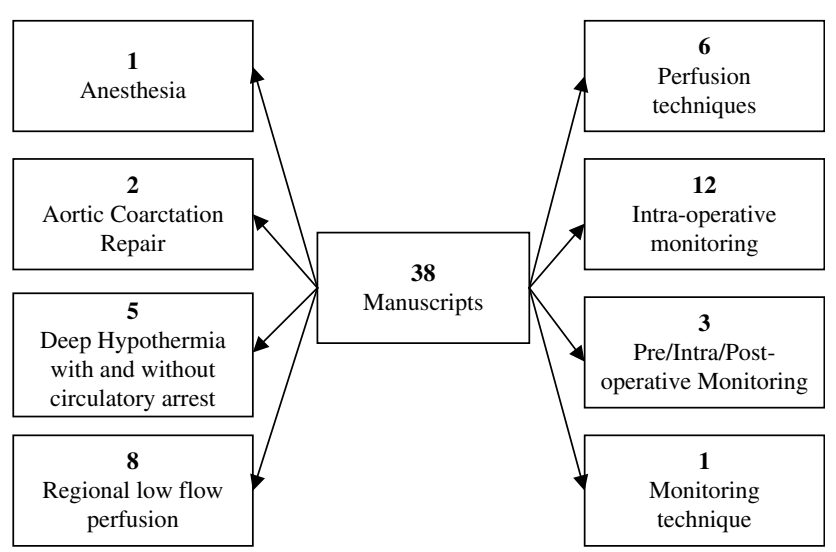

FIGURE 3. Classification of NIRS monitoring in the operating room. and do not represent primary data. In addition, negative studies often do not reach publication, which can favor the treatment. Meta-analyses represent a type of systematic review that involves formal quantitative analyses of the summarized information. Meta-analyses require similar methodologies and outcomes measures for a summary statistic. With the wide variability in devices, small sample size, and variable end points, this was not possible with the available literature. Owing to the strength of minimizing bias, systematic reviews play an important role in clinical and health care policy decision-making.

Many centers, and even entire countries, have adopted NIRS as a standard of care (forum discussion at 2007 Congenital Heart Surgeons Society Meeting). Yet, no level I evidence-based medical research has been published to indicate that clinical decision-making based on NIRS data is beneficial to the patient. Although the continued desire to mitigate the neurologic complications associated with CHD and its surgical intervention is laudable, the role for NIRS in meeting that goal remains clouded by the lack of reliable scientific evidence.

This study provides a comprehensive review of the scientific literature on NIRS for patients with CHD. The majority of studies reporting on NIRS for this patient population are limited by their case series design, with no appropriate comparison groups, and with small sample sizes. In addition, the NIRS technology has changed significantly since its inception. The literature reflects these changes over time with 6 different NIRS technologies represented in articles we reviewed. Although all of the devices are based on the same theoretical premise of the monitoring of regional oxygenation, they employ various measurement indices, making it difficult to cull the data from multiple studies for comparison. The significant variability in NIRS measurements, temporally and between individual patients, precludes the establishment of absolute threshold values for tissue ischemia. Relative values and individual patient trends have been used rather than absolute values. However, there is only limited evidence to indicate that these correlate with clinical outcomes. ${ }^{18,41}$ Furthermore, the wide heterogeneity in anatomy and physiology in CHD patients results in 
varying baseline levels of oxygenation. In combination with the small sample sizes, the diverse patient populations studied cause extrapolation to the overall CHD population to be challenging, if not impossible.

The available data suggest that multimodality monitoring of cerebral perfusion, including NIRS, may be a useful adjunct to prevent neurologic injury. ${ }^{18}$ The current literature on the use of NIRS alone for CHD patients does not demonstrate a clinical improvement in short-term neurologic outcome. There are no prospective data evaluating NIRS findings with direct clinical outcomes. The data correlating NIRS findings with indirect measures of neurologic outcome, such as MRI or mortality, are also limited. ${ }^{19,21,22}$

In assessing the potential role of NIRS monitoring in CHD, it is important to emphasize its unique qualities, including noninvasive, continuous, and real-time measurement of regional tissue oxygen saturation. However, caution must be exercised in extrapolating regional measurements to global findings. For example, alterations in regional oxygen saturation may reflect local changes and not necessarily indicate global hypoperfusion. Conversely, regional changes in oxygenation may be earlier, more sensitive indicators of impending multisystem organ injury. To date, no study has validated the correlation of NIRS measurements with other measurements of low cardiac output states. This is an important distinction when analyzing the literature in that reports of low regional cerebral oxygenation measurements do not necessarily indicate a low cardiac output state or global altered cerebral perfusion.

Future research needs to focus on how the addition of this regional oxygen saturation adds value to the clinical setting, rather than attempts to correlate NIRS with previously established global measurements of perfusion. Most important, before universal implementation of this technology, it is essential that rigorous clinical trials be performed to demonstrate improved clinical outcomes with the addition of NIRS monitoring.

\section{References}

1. Menaché CC, du Plessis AJ, Wessel DL, Jonas RA, Newburger JW. Current incidence of acute neurologic complications after open-heart operations in children. Ann Thorac Surg. 2002;73:1752-8.

2. Shillingford AJ, Wernovsky G. Academic performance and behavioral difficulties after neonatal and infant heart surgery. Pediatr Clin North Am. 2004;51:1625-39, ix.

3. Ghanayem NS, Mitchell ME, Tweddell JS, Hoffman GM. Monitoring the brain before, during, and after cardiac surgery to improve long-term neurodevelopmental outcomes. Cardiol Young. 2006;16(Suppl. 3):103-9.

4. Hoffman GM. Detection and prevention of neurologic injury in the intensive care unit. Cardiol Young. 2005;15(Suppl. 1):149-53.

5. Andropoulos DB, Stayer SA, Diaz LK, Ramamoorthy C. Neurological monitoring for congenital heart surgery. Anesth Analg. 2004;99:1365-75; table of contents.

6. Fraser CD Jr, Andropoulos DB. Neurologic monitoring for special cardiopulmonary bypass techniques. Semin Thorac Cardiovasc Surg Pediatr Card Surg Annu. 2004; 7:125-32.

7. Hoffman GM. Pro: near-infrared spectroscopy should be used for all cardiopulmonary bypass. J Cardiothorac Vasc Anesth. 2006;20:606-12.

8. Hoffman GM. Neurologic monitoring on cardiopulmonary bypass: what are we obligated to do? Ann Thorac Surg. 2006;81:S2373-80.
9. Wolfberg AJ, du Plessis AJ. Near-infrared spectroscopy in the fetus and neonate. Clin Perinatol. 2006;33:707-28, viii.

10. Lozano S, Mossad E. Cerebral function monitors during pediatric cardiac surgery: can they make a difference? J Cardiothorac Vasc Anesth. 2004;18:645-56.

11. Zimmerman AT, Ibsen LM. Advances in postoperative care of pediatric cardiac patients. Curr Opin Anesthesiol. 2004;17:241-6.

12. Soul JS, du Plessis AJ. New technologies in pediatric neurology. Near-infrared spectroscopy. Semin Pediatr Neurol. 1999;6:101-10.

13. Golej J, Trittenwein G. Early detection of neurologic injury and issues of rehabilitation after pediatric cardiac extracorporeal membrane oxygenation. Artif Organs. 1999;23:1020-5.

14. Nollert G, Shin'oka T, Jonas RA. Near-infrared spectrophotometry of the brain in cardiovascular surgery. Thorac Cardiovasc Surg. 1998;46:167-75.

15. du Plessis AJ. Near-infrared spectroscopy for the in vivo study of cerebral hemodynamics and oxygenation. Curr Opin Pediatr. 1995;7:632-9.

16. LeBlanc JG, Blackstock D, Macnab AJ, Gagnon F, Gagnon R, Russell J, et al. Effects of propofol on cerebral oxygenation during cardiopulmonary bypass in children. Can J Anaesth. 2000;47:1082-9.

17. Toet MC, Flinterman A, Laar I, Vries JW, Bennink GB, Uiterwaal CS, et al. Cerebral oxygen saturation and electrical brain activity before, during, and up to 36 hours after arterial switch procedure in neonates without pre-existing brain damage: its relationship to neurodevelopmental outcome. Exp Brain Res. 2005; 165:343-50.

18. Austin EH 3rd, Edmonds HL Jr, Auden SM, Seremet V, Niznik G, Sehic A, et al. Benefit of neurophysiologic monitoring for pediatric cardiac surgery. $J$ Thorac Cardiovasc Surg. 1997;114:707-15, 717; discussion 715-6.

19. Dent CL, Spaeth JP, Jones BV, Schwartz SM, Glauser TA, Hallinan B, et al. Brain magnetic resonance imaging abnormalities after the Norwood procedure using regional cerebral perfusion. J Thorac Cardiovasc Surg. 2006;131:190-7.

20. Fenton KN, Freeman K, Glogowski K, Fogg S, Duncan KF. The significance of baseline cerebral oxygen saturation in children undergoing congenital heart surgery. Am J Surg. 2005; 190:260-3.

21. McQuillen PS, Barkovich AJ, Hamrick SE, Perez M, Ward P, Glidden DV, et al. Temporal and anatomic risk profile of brain injury with neonatal repair of congenital heart defects. Stroke. 2007;38(2 Suppl):736-41.

22. Fenton KN, Lessman K, Glogowski K, Fogg S, Duncan KF. Cerebral oxygen saturation does not normalize until after stage 2 single ventricle palliation. Ann Thorac Surg. 2007;83:1431-6.

23. Kurth CD, Steven JL, Montenegro LM, Watzman HM, Gaynor JW, Spray TL, et al. Cerebral oxygen saturation before congenital heart surgery. Ann Thorac Surg. 2001;72:187-92.

24. Takami T, Yamamura H, Inai K, Nishikawa Y, Takei Y, Hoshika A, et al. Monitoring of cerebral oxygenation during hypoxic gas management in congenital heart disease with increased pulmonary blood flow. Pediatr Res. 2005;58:521-4.

25. Ramamoorthy C, Tabbutt S, Kurth CD, Steven JM, Montenegro LM, Durning S, et al. Effects of inspired hypoxic and hypercapnic gas mixtures on cerebral oxygen saturation in neonates with univentricular heart defects. Anesthesiology. 2002;96:283-8.

26. McQuillen PS, Nishimoto MS, Bottrell CL, Fineman LD, Hamrick SE, Glidden DV, et al. Regional and central venous oxygen saturation monitoring following pediatric cardiac surgery: concordance and association with clinical variables. Pediatr Crit Care Med. 2007;8:154-60.

27. Li J, Van Arsdell GS, Zhang G, Cai S, Humpl T, Caldarone CA, et al. Assessment of the relationship between cerebral and splanchnic oxygen saturations measured by near-infrared spectroscopy and direct measurements of systemic haemodynamic variables and oxygen transport after the Norwood procedure. Heart. 2006;92:1678-85.

28. Mott AR, Alomrani A, Tortoriello TA, Perles Z, East DL, Stayer SA. Changes in cerebral saturation profile in response to mechanical ventilation alterations in infants with bidirectional superior cavopulmonary connection. Pediatr Crit Care Med. 2006;7:346-50.

29. Bassan H, Gauvreau K, Newburger JW, Tsuji M, Limperopoulos C, Soul JS, et al. Identification of pressure passive cerebral perfusion and its mediators after infant cardiac surgery. Pediatr Res. 2005;57:35-41.

30. Nagdyman N, Fleck T, Bitterling B, Ewert P, Abdul-Khaliq H, Stiller B, et al. Influence of intravenous sildenafil on cerebral oxygenation measured by near-infrared spectroscopy in infants after cardiac surgery. Pediatr Res. 2006;59:462-5.

31. Tortoriello TA, Stayer SA, Mott AR, McKenzie ED, Fraser CD, Andropoulos DB, et al. A noninvasive estimation of mixed venous oxygen saturation using near-infrared spectroscopy by cerebral oximetry in pediatric cardiac surgery patients. Paediatr Anaesth. 2005;15:495-503.

32. Nagdyman N, Fleck T, Barth S, Abdul-Khaliq H, Stiller B, Ewert P, et al. Relation of cerebral tissue oxygenation index to central venous oxygen saturation in children. Intensive Care Med. 2004;30:468-71. 
33. Giacomuzzi C, Heller E, Mejak B, You J, Ungerleider R, Silberbach M. Assessing the brain using near-infrared spectroscopy during postoperative ventricular circulatory support. Cardiol Young. 2005; 15(Suppl. 1):154-8.

34. Bhutta AT, Ford JW, Parker JG, Prodhan P, Fontenot EE, Seib PM, et al. Noninvasive cerebral oximeter as a surrogate for mixed venous saturation in children. Pediatr Cardiol. 2007;28:34-41.

35. Levy RJ, Stern WB, Minger KI, Montenegro LM, Ravishankar C, Rome JJ, et al. Evaluation of tissue saturation as a noninvasive measure of mixed venous saturation in children. Pediatr Crit Care Med. 2005;6:671-5.

36. Nagdyman N, Fleck T, Schubert S, Ewert P, Peters B, Lange PE, et al. Comparison between cerebral tissue oxygenation index measured by near-infrared spectroscopy and venous jugular bulb saturation in children. Intensive Care Med. 2005;31:846-50.
37. Daubeney PE, Pilkington SN, Janke E, Charlton GA, Smith DC, Webber SA. Cerebral oxygenation measured by near-infrared spectroscopy: comparison with jugular bulb oximetry. Ann Thorac Surg. 1996;61:930-4.

38. Kirshbom PM, Forbess JM, Kogon BE, Simsic JM, Kim DW, Raviele AA, et al. Cerebral near infrared spectroscopy is a reliable marker of systemic perfusion in awake single ventricle children. Pediatr Cardiol. 2007;28:42-5.

39. Watzman HM, Kurth CD, Montenegro LM, Rome J, Steven JM, Nicolson SC. Arterial and venous contributions to near-infrared cerebral oximetry. Anesthesiology. 2000;93:947-53.

40. de Vries JW, Hoorntje TM, Sreeram N. Neurophysiological effects of pediatric balloon dilatation procedures. Pediatr Cardiol. 2000;21:461-4.

41. Kurth CD, Steven JM, Nicolson SC. Cerebral oxygenation during pediatric cardiac surgery using deep hypothermic circulatory arrest. Anesthesiology. 1995;82:74-82.

Access to The Journal of Thoracic and Cardiovascular Surgery Online is reserved for print subscribers!

Full-text access to The Journal of Thoracic and Cardiovascular Surgery Online is available for all print subscribers. To activate your individual online subscription, please visit The Journal of Thoracic and Cardiovascular Surgery Online, point your browser to http://www.mosby.com/itcvs, follow the prompts to activate your online access, and follow the instructions. To activate your account, you will need your subscriber account number, which you can find on your mailing label (note: the number of digits in your subscriber account number varies from 6 to 10). See the example below in which the subscriber account number has been circled:

\section{Sample mailing label}

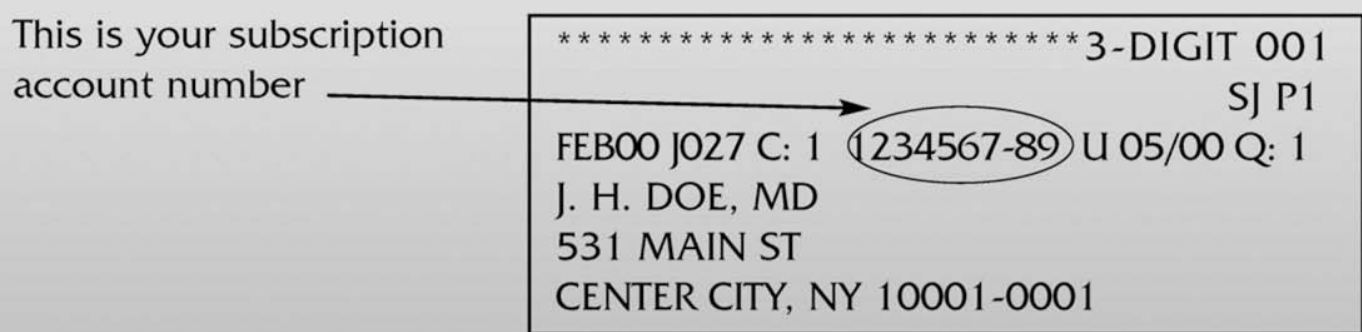

Personal subscriptions to The Journal of Thoracic and Cardiovascular Surgery Online are for individual use only and may not be transferred. Use of The Journal of Thoracic and Cardiovascular Surgery Online is subject to agreement to the terms and conditions as indicated online. 


\section{E-References}

E42. Berens RJ, Stuth EA, Robertson FA, Jaquiss RD, Hoffman GM, Troshynski TJ, et al. Near infrared spectroscopy monitoring during pediatric aortic coarctation repair. Paediatr Anaesth. 2006;16:777-81.

E43. Azakie A, Muse J, Gardner M, Skidmore KL, Miller SP, Karl TR, et al. Cerebral oxygen balance is impaired during repair of aortic coarctation in infants and children. J Thorac Cardiovasc Surg. 2005;130:830-6.

E44. Kussman BD, Wypij D, DiNardo JA, Newburger J, Jonas RA, Bartlett J, et al. An evaluation of bilateral monitoring of cerebral oxygen saturation during pediatric cardiac surgery. Anesth Analg. 2005;101:1294-300.

E45. du Plessis AJ, Newburger J, Jonas RA, Hickey P, Naruse H, Tsuji M, et al. Cerebral oxygen supply and utilization during infant cardiac surgery. Ann Neurol. 1995;37:488-97.

E46. Kurth CD, Steven JM, Nicolson SC, Chance B, Delivoria-Papadopoulos M. Kinetics of cerebral deoxygenation during deep hypothermic circulatory arrest in neonates. Anesthesiology. 1992;77:656-61.

E47. Greeley WJ, Bracey VA, Ungerleider RM, Greibel JA, Kern FH, Boyd JL, et al. Recovery of cerebral metabolism and mitochondrial oxidation state is delayed after hypothermic circulatory arrest. Circulation. 1991;84(5 Suppl):III400-6.

E48. Hofer A, Haizinger B, Geiselseder G, Mair R, Rehak P, Gombotz H. Monitoring of selective antegrade cerebral perfusion using near infrared spectroscopy in neonatal aortic arch surgery. Eur J Anaesthesiol. 2005;22:293-8.

E49. Andropoulos DB, Diaz LK, Fraser CD Jr, McKenzie ED, Stayer SA. Is bilateral monitoring of cerebral oxygen saturation necessary during neonatal aortic arch reconstruction? Anesth Analg. 2004;98:1267-72, table of contents.

E50. Hoffman GM, Stuth EA, Jaquiss RD, Vanderwal PL, Staudt SR, Troshynski TJ, et al. Changes in cerebral and somatic oxygenation during stage 1 palliation of hypoplastic left heart syndrome using continuous regional cerebral perfusion. J Thorac Cardiovasc Surg. 2004;127:223-33.

E51. Kilpack VD, Stayer SA, McKenzie ED, Fraser CD Jr, Andropoulos DB. Limiting circulatory arrest using regional low flow perfusion. J Extra Corpor Technol. 2004;36:133-8.

E52. Andropoulos DB, Stayer SA, McKenzie ED, Fraser CD Jr. Novel cerebral physiologic monitoring to guide low-flow cerebral perfusion during neonatal aortic arch reconstruction. J Thorac Cardiovasc Surg. 2003;125:491-9.

E53. Andropoulos DB, Stayer SA, McKenzie ED, Fraser CD Jr. Regional low-flow perfusion provides comparable blood flow and oxygenation to both cerebral hemispheres during neonatal aortic arch reconstruction. $J$ Thorac Cardiovasc Surg. 2003;126:1712-7.

E54. Pigula FA, Gandhi SK, Siewers RD, Davis PJ, Webber SA, Nemoto EM. Regional low-flow perfusion provides somatic circulatory support during neonatal aortic arch surgery. Ann Thorac Surg. 2001;72:401-6; discussion 406-7.

E55. Pigula FA, Nemoto EM, Griffith BP, Siewers RD. Regional low-flow perfusion provides cerebral circulatory support during neonatal aortic arch reconstruction. J Thorac Cardiovasc Surg. 2000;119:331-9.

E56. Han SH, Kim CS, Kim SD, Bahk JH, Park YS. The effect of bloodless pump prime on cerebral oxygenation in paediatric patients. Acta Anaesthesiol Scand. 2004;48:648-52.
E57. Sakamato T, Kurosawa H, Shin'oka T, Aoki M, Isomatsu Y. The influence of pH strategy on cerebral and collateral circulation during hypothermic cardiopulmonary bypass in cyanotic patients with heart disease: Results of a randomized trial and real-time Monitoring. J Thorac Cardiovasc Surg. 2004;127:12-9.

E58. Shaaban Ali M, Harmer M, Elliott M, Thomas AL, Kirkham F. A pilot study of evaluation of cerebral function by S100beta protein and near-infrared spectroscopy during cold and warm cardiopulmonary bypass in infants and children undergoing open-heart surgery. Anaesthesia. 2004;59:20-6.

E59. Wardle SP, Yoxall CW, Weindling AM. Cerebral oxygenation during cardiopulmonary bypass. Arch Dis Child. 1998;78:26-32.

E60. Chow G, Roberts IG, Edwards AD, Lloyd-Thomas A, Wade A, Elliott MJ, et al. The relation between pump flow rate and pulsatility on cerebral hemodynamics during pediatric cardiopulmonary bypass. J Thorac Cardiovasc Surg.1997;114:568-77.

E61. Kurth CD, Steven JM, Nicolson SC, Jacobs ML. Cerebral oxygenation during cardiopulmonary bypass in children. J Thorac Cardiovasc Surg.1997;113: 71-8; discussion 78-9.

E62. Murayama H, Tamaki S, Usui A, Ueda Y. Measurement of cerebral-oxygenation status when commencing cardiopulmonary bypass in pediatric open-heart surgery. Ann Thorac Cardiovasc Surg. 2006;12:105-12.

E63. Hayashida M, Kin N, Tomioka T, Orii R, Sekiyama H, Usui H, et al. Cerebral ischaemia during cardiac surgery in children detected by combined monitoring of BIS and near-infrared spectroscopy. Br J Anaesth. 2004;92:662-9.

E64. Morimoto Y, Niida Y, Hisano K, Hua Y, Kemmotsu O, Murashita T, et al. Changes in cerebral oxygenation in children undergoing surgical repair of ventricular septal defects. Anaesthesia. 2003;58:77-83.

E65. Daubeney PE, Smith DC, Pilkington SN, Lamb RK, Monro JL, Tsang VT, et al. Cerebral oxygenation during paediatric cardiac surgery: identification of vulnerable periods using near infrared spectroscopy. Eur J Cardiothorac Surg. 1998;13:370-7.

E66. Chow G, Roberts IG, Fallon P, Onoe M, Lloyd-Thomas A, Elliott MJ, et al. The relation between arterial oxygen tension and cerebral blood flow during cardiopulmonary bypass. Eur J Cardiothorac Surg. 1997;11:633-9.

E67. Van BelF, Zeeuwe PE, Dorrepaal CA, Benders MJ, Van de Bor M, Hardjowijono $\mathrm{R}$. Changes in cerebral hemodynamics and oxygenation during hypothermic cardiopulmonary bypass in neonates and infants. Biol Neonate. 1996;70:141-54.

E68. Fallon P, Roberts IG, Kirkham FJ, Edwards AD, Lloyd-Thomas A, Elliott MJ. Cerebral blood volume response to changes in carbon dioxide tension before and during cardiopulmonary bypass in children, investigated by near infrared spectroscopy. Eur J Cardiothorac Surg. 1994;8:130-4.

E69. Skov L, Greisen G. Apparent cerebral cytochrome aa3 reduction during cardiopulmonary bypass in hypoxaemic children with congenital heart disease. A critical analysis of in vivo near-infrared spectrophotometric data. Physiol. Meas. 1994; 15:447-57.

E70. Fallon P, Roberts I, Kirkham FJ, Elliott MJ, Lloyd-Thomas A, Maynard R, et al. Cerebral hemodynamics during cardiopulmonary bypass in children using nearinfrared spectroscopy. Ann Thorac Surg. 1993;56:1473-7.

E71. Roberts IG, Fallon P, Kirkham FJ, Kirshbom PM, Cooper CE, Elliott MJ, et al. Measurement of cerebral blood flow during cardiopulmonary bypass with nearinfrared spectroscopy. J Thorac Cardiovasc Surg.1998;115:94-102. 


\begin{tabular}{lcccc}
\hline \multicolumn{1}{c}{ Author } & Year & Study design* & Device & Patient population \\
\hline $\begin{array}{c}\text { Anesthesia } \\
\text { LeBlanc et al }\end{array}$ & \multirow{2}{*}{2000} & Randomized & NIRO & $\begin{array}{c}\text { Elective ASD or VSD with } \\
(\mathrm{n}=11) \text { or without } \\
\end{array}$ \\
& & & $(\mathrm{n}=13)$ propofol
\end{tabular}

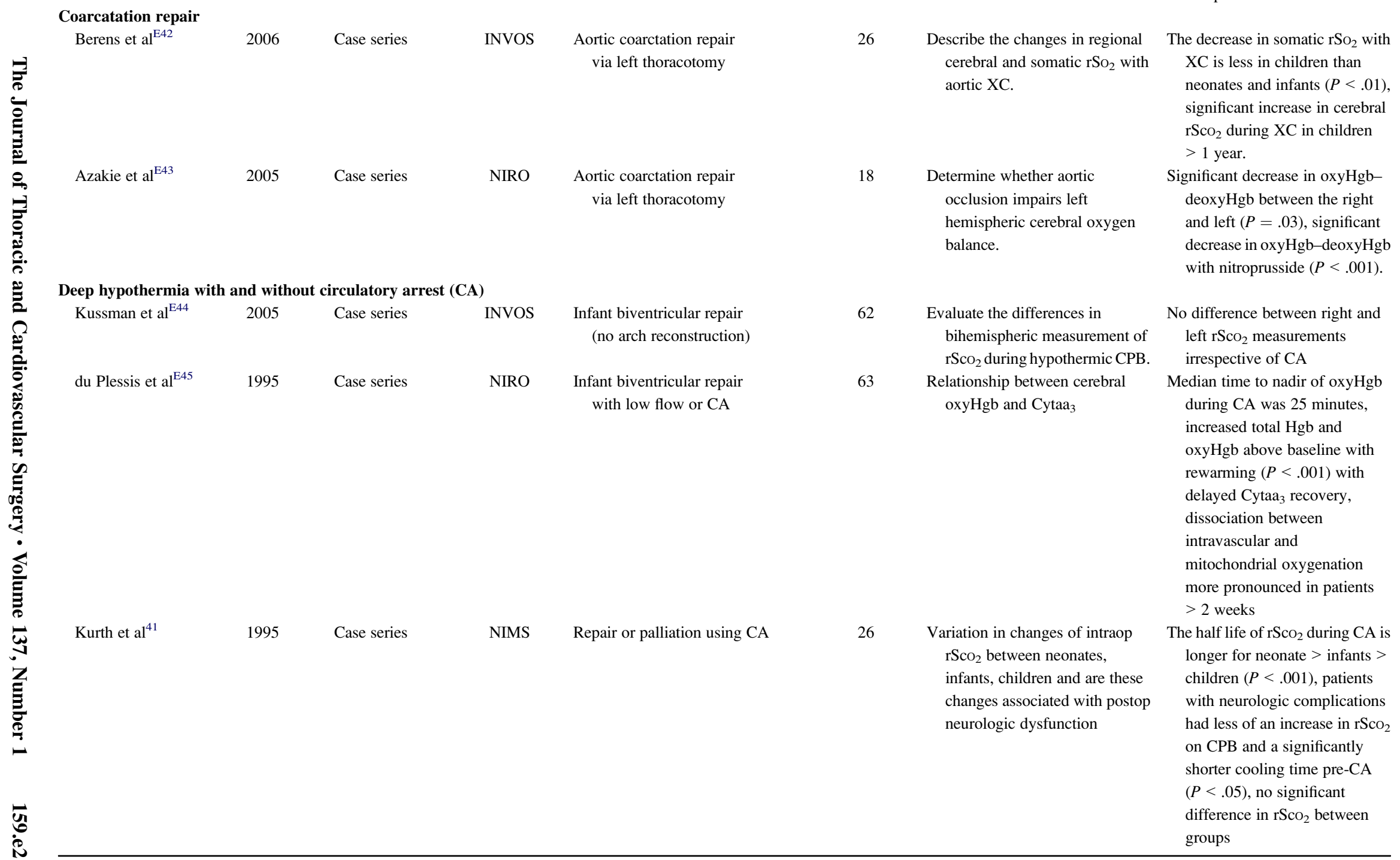

Effect of propofol on the redox Propofol has similar effects on status of $\mathrm{Cytaa}_{3}$ and neurologic $\quad \mathrm{Cytaa}_{3}$ as hypothermia; no complications.

gross neurologic

complications. neonates and infants $(P<.01)$

in

nificant decrease in oxyHgbinyHgb-deoxyHg difference between right and

during CA was 25 minutes, increased total $\mathrm{Hgb}$ and (P< baseline with delayed $\mathrm{Cytaa}_{3}$ recovery, 


\begin{tabular}{|c|c|c|c|c|c|c|c|}
\hline Author & Year & Study design* & Device & Patient population & Total number & Primary end point & Results \\
\hline Kurth et $\mathrm{al}^{\mathrm{E} 46}$ & 1992 & Case series & NIMS & $\begin{array}{l}\text { Neonates undergoing surgery } \\
\text { with CA }\end{array}$ & 17 & $\begin{array}{l}\text { Kinetics of oxyHgb in neonates } \\
\text { during DHCA }\end{array}$ & $\begin{array}{l}\text { OxyHgb increases during cooling } \\
(P<.05) \text {, decreases during CA } \\
\text { in a curvilinear distribution } \\
\text { until a plateau at } 40 \text { minutes } \\
(P<.001) \text {, and returns to } \\
\text { baseline with rewarming }\end{array}$ \\
\hline Greeley et al ${ }^{\mathrm{E} 47}$ & 1991 & Case series & NIRO & $\begin{array}{l}\text { Deep hypothermia with } \\
\text { or without CA in neonates } \\
\text { and children }\end{array}$ & 15 & $\begin{array}{l}\text { The effect of } \mathrm{CA} \text { on } \mathrm{CMRO}_{2} \text { and } \\
\text { oxygenation }\end{array}$ & $\begin{array}{l}\text { OxyHgb and } \mathrm{Cytaa}_{3} \text { decreased } \\
\text { during } \mathrm{CA}, \mathrm{CMRO}_{2} \text { and Cytaa } \\
\text { remained lower than baseline } \\
\text { after } \mathrm{CPB} \text { with } \mathrm{CA} \text { but returned } \\
\text { to normal in non-CA patients } \\
(P<.01) \text {. }\end{array}$ \\
\hline \multicolumn{8}{|c|}{ Regional low flow perfusion (RLFP) } \\
\hline Hofer et $\mathrm{al}^{\mathrm{E} 48}$ & 2005 & Case series & INVOS & $\begin{array}{l}\text { RLFP for Norwood } \\
\text { procedure }\end{array}$ & 10 & $\begin{array}{l}\text { Correlation of bilateral NIRS } \\
\text { monitoring during RLFP with } \\
\text { variable flow rates. }\end{array}$ & $\begin{array}{l}\text { There was a significant decrease in } \\
\text { bilateral } \mathrm{rScO}_{2} \text { and jugular } \mathrm{SvO}_{2} \\
\text { with decreasing RLFP rates } \\
(P<.001) . \text { Wide interindivi- } \\
\text { dual variation in } \mathrm{rScO}_{2} \text {. }\end{array}$ \\
\hline $\begin{array}{l}\text { Andropoulos et } \mathrm{al}^{\mathrm{E} 49} \\
\text { (same patient }^{\text {sample })+}\end{array}$ & 2004 & Case series & INVOS & $\begin{array}{l}\text { RLFP for Norwood } \\
\text { procedure or aortic arch } \\
\text { reconstruction }\end{array}$ & 19 & $\begin{array}{l}\text { Correlation of bilateral NIRS } \\
\text { monitoring during RLFP } \\
\text { adjusted for CBFV with TCD. }\end{array}$ & $\begin{array}{l}\text { During RLFP, correlation between } \\
\text { hemispheres was poor and only } \\
\text { partially returned to baseline } \\
\text { after RLFP with the left side } \\
\text { always being the lower value. }\end{array}$ \\
\hline Hoffman et al ${ }^{\mathrm{E} 50}$ & 2004 & Case series & INVOS & $\begin{array}{l}\text { RLFP for Norwood } \\
\text { procedure }\end{array}$ & 9 & $\begin{array}{l}\text { Relative changes in cerebral and } \\
\text { somatic oxygenation during } \\
\text { RLFP adjusted for } \mathrm{rScO}_{2} \text { and } \\
\text { CBFV. }\end{array}$ & $\begin{array}{l}\mathrm{rScO}_{2} \text { was maintained during } \\
\mathrm{RLFP} \text { but decreased below } \\
\text { baseline after CPB. There was } \\
\text { no correlation between cerebral } \\
\text { and somatic oxygenation at any } \\
\text { time point. }\end{array}$ \\
\hline $\begin{array}{l}\text { Kilpack et } \mathrm{al}^{\mathrm{E} 51} \\
\quad \text { (same patient } \\
\text { sample)* }\end{array}$ & 2004 & Case series & INVOS & $\begin{array}{l}\text { RLFP for Norwood } \\
\text { procedure or aortic arch } \\
\text { reconstruction }\end{array}$ & 34 & $\begin{array}{l}\text { Demonstrate maintenance of } \\
\text { adequate } \mathrm{rScO}_{2} \text { with RLFP } \\
\text { when } \mathrm{CPB} \text { flow adjusted for } \\
\mathrm{rScO}_{2} \text { and } \mathrm{CBFV} \text {. }\end{array}$ & $\begin{array}{l}\text { No difference in } \mathrm{rSCO}_{2} \text { on full flow } \\
\mathrm{CPB} \text {, RLFP, and resumption of } \\
\text { full flow CPB. However, CPB } \\
\text { flow was adjusted to maintain } \\
\text { value within } 10 \% \text { of baseline. }\end{array}$ \\
\hline 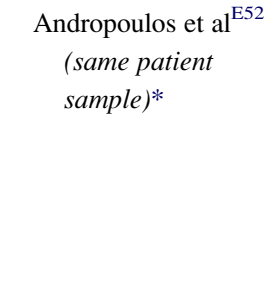 & 2003 & Case series & INVOS & $\begin{array}{l}\text { RLFP for Norwood } \\
\text { procedure or aortic arch } \\
\text { reconstruction }\end{array}$ & 34 & $\begin{array}{l}\text { Describe the addition of } \mathrm{CBFV} \\
\text { monitoring by } \mathrm{TCD} \text { to } \mathrm{rScO}_{2} \text { as } \\
\text { a guide to bypass flow during } \\
\text { RLFP. }\end{array}$ & $\begin{array}{l}\text { Poor correlation between MAP } \\
\text { and required CPB flow. 14/34 } \\
\text { had } \mathrm{rScO}_{2}>95 \% \text { during RLFP } \\
\text { increasing the risk of } \\
\text { hyperperfusion. No outcomes } \\
\text { correlation for the addition of } \\
\mathrm{CBFV} \text { to } \mathrm{rScO}_{2} \text { to guide CPB } \\
\text { flow. }\end{array}$ \\
\hline
\end{tabular}




\begin{tabular}{|c|c|c|c|c|c|c|c|}
\hline Author & Year & Study design* & Device & Patient population & Total number & Primary end point & Results \\
\hline $\begin{array}{l}\text { Andropoulos et } \mathrm{al}^{\mathrm{E} 53} \\
\text { (same patient sample)+ }\end{array}$ & 2003 & Case series & INVOS & $\begin{array}{l}\text { RLFP for Norwood } \\
\text { procedure or aortic arch } \\
\text { reconstruction }\end{array}$ & 20 & $\begin{array}{l}\text { Demonstrate the correlation } \\
\text { between CBVI based on NIRS } \\
\text { and CBFV by TCD. }\end{array}$ & $\begin{array}{l}\text { Poor correlation between CBVI } \\
\text { and CBFV. Right sided CBFV } \\
\text { did not correlate with RLFP } \\
\text { flow rate. }\end{array}$ \\
\hline Pigula et $\mathrm{al}^{\mathrm{E} 54}$ & 2001 & Case series & INVOS & $\begin{array}{l}\text { RLFP for Norwood } \\
\text { procedure or aortic arch } \\
\text { reconstruction }\end{array}$ & 15 & $\begin{array}{l}\text { Ability of RLFP to provide } \\
\text { subdiaphragmatic somatic } \\
\text { circulatory support as measured } \\
\text { by somatic NIRS. }\end{array}$ & $\begin{array}{l}\text { Abdominal aortic blood pressure, } \\
\text { quadriceps blood volume, and } \\
\text { quadriceps } \mathrm{rSO}_{2} \text { were } \\
\text { significantly greater during } \\
\text { RLFP than DHCA }(P<.05) \text {. }\end{array}$ \\
\hline Pigula et al ${ }^{\mathrm{E} 55}$ & 2000 & Case series & INVOS/NIRO & $\begin{array}{l}\text { Neonatal aortic arch } \\
\text { reconstruction with RLFP } \\
(\mathrm{n}=6) \text { and neonatal } \\
\text { cardiac repair with DHCA } \\
(\mathrm{n}=6)\end{array}$ & 12 & $\begin{array}{l}\text { Experiential report of using NIRS } \\
\text { guided RLFP versus DHCA. }\end{array}$ & $\begin{array}{l}\text { RLFP flow rate of } 20 \mathrm{~mL} \cdot \mathrm{kg}^{-1} \text {. } \\
\min ^{-1} \text { maintained baseline } \\
\text { values. } \mathrm{rScO}_{2} \text { and CBVI } \\
\text { decrease significantly during } \\
\text { DHCA but are maintained } \\
\text { during RLFP. }\end{array}$ \\
\hline \multicolumn{8}{|l|}{ Perfusion techniques } \\
\hline Han et $\mathrm{a}^{\mathrm{E} 56}$ & 2004 & Randomized & INVOS & $\begin{array}{l}\text { Repair of ASD or VSD with } \\
\text { bloodless }(\mathrm{n}=18) \text { or blood } \\
(\mathrm{n}=18) \text { prime }\end{array}$ & 36 & $\begin{array}{l}\text { Compare the effect of blood } \\
\text { versus bloodless } \mathrm{CPB} \text { prime on } \\
\mathrm{rSCO}_{2} .\end{array}$ & $\begin{array}{l}\mathrm{rScO}_{2} \text { decreases below baseline in } \\
\text { both groups at the start of } \mathrm{CPB} \\
\text { and during rewarming }(P<.001) \\
\text { with a greater reduction in the } \\
\text { bloodless prime group }(P<.01) \text {. }\end{array}$ \\
\hline Sakamato et al ${ }^{\mathrm{E} 7}$ & 2004 & Randomized & NIRO & $\begin{array}{l}\text { CPB in cyanotic patients using } \\
\text { alpha-stat }(\mathrm{n}=19) \text { versus } \\
\text { pH-stat }(\mathrm{n}=21) \text { strategy }\end{array}$ & 40 & $\begin{array}{l}\text { Evaluate the effect of } \mathrm{pH} \\
\text { strategies on } \mathrm{rScO}_{2} \text { and SPCC. }\end{array}$ & $\begin{array}{l}\mathrm{rScO}_{2} \text { was significantly lower }(P= \\
.008) \text { and the deoxyhgb was } \\
\text { significantly higher }(\mathrm{p}<0.0001) \\
\text { with alpha-stat. SPCC was } \\
\text { significantly lower with } \mathrm{pH} \text {-stat } \\
(P<.0001) \text {. }\end{array}$ \\
\hline Shaaban et al ${ }^{\mathrm{E} 58}$ & 2004 & Case series & NIRO & $\begin{array}{l}\text { Cold }\left(25^{\circ} \mathrm{C}\right)(\mathrm{n}=9) \text { versus warm } \\
\quad\left(35^{\circ} \mathrm{C}\right)(\mathrm{n}=9) \mathrm{CPB} \text { for } \\
\text { biventricular repair }\end{array}$ & 18 & $\begin{array}{l}\text { Compare the effect of cold versus } \\
\text { warm CPB in terms of extent of } \\
\text { cerebral damage (measured by } \\
\text { S100ß) and oxyHgb. }\end{array}$ & $\begin{array}{l}\text { S100 } \beta \text { increased significantly in } \\
\text { both groups. No correlation } \\
\text { between } \mathrm{S} 100 \beta \text { and NIRS } \\
\text { measurements except lowest } \\
\text { post-CPB Cytaa }{ }_{3} \text { level }(P= \\
.016) \text {. TOI was significantly } \\
\text { impaired during rewarming. }\end{array}$ \\
\hline Wardle et $\mathrm{al}^{\mathrm{E} 59}$ & 1998 & Case series & NIRO & $\begin{array}{l}\text { Deep hypothermia }\left(15^{\circ} \mathrm{C}\right)(\mathrm{n}= \\
\text { 15) versus mild-moderate } \\
\text { hypothermia }\left(22^{\circ}-28^{\circ} \mathrm{C}\right)(\mathrm{n}= \\
\text { 15) } \mathrm{CPB}\end{array}$ & 30 & $\begin{array}{l}\text { Investigate the effect of } \\
\text { hypothermia and CA on } \\
\text { cerebral FOE. }\end{array}$ & $\begin{array}{l}\text { FOE increases with the institution } \\
\text { of CPB in cyanotic patients. } \\
\text { FOE decreases during cooling } \\
\text { and only increases during } \\
\text { rewarming in the continuous } \\
\text { flow group. No significant } \\
\text { difference between groups at } \\
\text { any time in Cytaa. }\end{array}$ \\
\hline
\end{tabular}




\begin{tabular}{|c|c|c|c|c|c|c|c|}
\hline Author & Year & Study design* & Device & Patient population & Total number & Primary end point & Results \\
\hline Chow et al ${ }^{\mathrm{E} 60}$ & 1997 & Randomized crossover & NIRO & $\begin{array}{l}\mathrm{CPB} \text { using pulsatile and } \\
\text { nonpulsatile flow }\end{array}$ & 40 & $\begin{array}{l}\text { Examine the relationship between } \\
\text { pump flow rate and cerebral } \\
\text { hemodynamics during pulsatile } \\
\text { and nonpulsatile CPB. }\end{array}$ & $\begin{array}{c}\mathrm{CBF} \text { decreased by } 36 \% \text { per } \mathrm{L} \cdot \mathrm{m}^{2} \\
\cdot \mathrm{min}^{-1} \text { decrease in pump flow } \\
\text { rate regardless of pulsatility. }\end{array}$ \\
\hline Kurth et $\mathrm{al}^{\mathrm{E} 61}$ & 1997 & Randomized & NIMS & $\begin{array}{l}\text { CPB: warm }(\mathrm{n}=10) \text {, hypothermic } \\
\left(25^{\circ} \mathrm{C}\right)(\mathrm{n}=10) \text {, hypothermic/ } \\
\text { low flow }(\mathrm{n}=9) \text {, and } \\
\text { hypothermic/low Hct }(\mathrm{n}=9)\end{array}$ & 38 & $\begin{array}{l}\text { Evaluate the effect of perfusate } \\
\text { temperature, pump flow rate, } \\
\text { and Hct on cerebral } \mathrm{O}_{2} \\
\text { extraction. }\end{array}$ & $\begin{array}{l}\mathrm{rScO}_{2} \text { increases during cooling } \\
(P<.001), \mathrm{rScO}_{2} \text { increased after } \\
\mathrm{CPB} \text { was discontinued in the } \\
\text { low flow and low Hct group. }\end{array}$ \\
\hline Fenton et $\mathrm{al}^{22}$ & 2007 & Retrospective & INVOS & $\begin{array}{l}\text { Single ventricle staged palliation } \\
(\mathrm{n}=34) \text { and ductus-dependent } \\
\text { complete repair }(\mathrm{n}=12)\end{array}$ & 46 & $\begin{array}{l}\text { Determine whether } \mathrm{rScO}_{2} \text { is } \\
\text { related to the stage of single } \\
\text { ventricle palliation. }\end{array}$ & $\begin{array}{l}\mathrm{rScO}_{2} \text { at the end of the operation } \\
\text { was significantly lower in } \\
\text { patients who died }(P=.01), \\
\mathrm{rScO} \mathrm{C}_{2} \text { decreases significantly } \\
\text { after stage } 1 \text { palliation }(P= \\
.001) \text { and increases after stage } 2 \\
\text { palliation }(P=.04) . \text { No } \\
\text { correlation with neurologic } \\
\text { complications. }\end{array}$ \\
\hline Murayama et $\mathrm{al}^{\mathrm{E} 62}$ & 2006 & Case series & NIRO & $\begin{array}{l}\text { Repair of cyanotic }(\mathrm{n}=10) \text { and } \\
\text { noncyanotic }(\mathrm{n}=10) \text { heart } \\
\text { defects }\end{array}$ & 20 & $\begin{array}{l}\text { Differences in } \mathrm{rScO}_{2} \text { at the } \\
\text { initiation of } \mathrm{CPB} \text { for cyanotic } \\
\text { and noncyanotic heart defects. }\end{array}$ & $\begin{array}{l}\text { Cerebral oxyHgb, deoxyHgb, and } \\
\text { total Hgb decrease and then } \\
\text { plateau on CPB. DeoxyHgb } \\
\text { and total Hbg decreased more } \\
\text { markedly in the cyanotic } \\
\text { patients }(P<.01) \text {. }\end{array}$ \\
\hline Fenton et $\mathrm{al}^{20}$ & 2005 & Retrospective & INVOS & $\begin{array}{l}\text { Repair of cyanotic and } \\
\text { noncyanotic CHD }\end{array}$ & 143 & $\begin{array}{l}\text { Determine CHD patient groups } \\
\text { with abnormally low baseline } \\
\mathrm{rScO}_{2} \text {. }\end{array}$ & $\begin{array}{l}\text { Preop } \mathrm{rScO}_{2} \text { is lower in cyanotic } \\
\text { and noncyanotic infants with } \\
\text { left-to-right shunts }(P<.01) \\
\text { but not in cyanotic infants } \\
\text { without left-to-right shunts. } \\
\text { Periop death was associated } \\
\text { with a baseline } \mathrm{rScO}_{2}<50 \% \text {. }\end{array}$ \\
\hline Hayashida et $\mathrm{al}^{\mathrm{E} 63}$ & 2004 & Case series & PSA-3N & $\begin{array}{l}\text { Noncyanotic } \mathrm{CHD} \\
\text { repaired with } \mathrm{CPB}\end{array}$ & 65 & $\begin{array}{l}\text { Measure the incidence of cerebral } \\
\text { ischemia using bispectral index } \\
\text { and NIRS in children having } \\
\text { cardiac surgery. }\end{array}$ & $\begin{array}{l}\text { Cerebral ischemia (defined as } \\
\text { abrupt decrease in both } \mathrm{rSCO}_{2} \\
\text { and bispectral index with acute } \\
\text { hypotension) was more } \\
\text { common and frequent in } \\
\text { children }<4 \text { years. } \mathrm{rScO}_{2} \text { was } \\
\text { more dependent on arterial } \\
\text { pressure in children }<4 \text { years. } \\
\text { Cerebral ischemia frequency } \\
\text { correlated negatively with } \mathrm{Hct} \\
(P<.0001) .\end{array}$ \\
\hline
\end{tabular}




\begin{tabular}{|c|c|c|c|c|c|c|c|}
\hline Author & Year & Study design* & Device & Patient population & Total number & Primary end point & Results \\
\hline Morimoto et $\mathrm{al}^{\mathrm{E} 64}$ & 2003 & Case series & NIRO & Repair of VSD & 16 & $\begin{array}{l}\text { Examined changes in cerebral } \\
\text { oxygenation using NIRS } \\
\text { during VSD repair. }\end{array}$ & $\begin{array}{l}\text { OxyHgb decreases on CPB with } \\
\text { no change in deoxyHgb. }\end{array}$ \\
\hline Daubeney et al ${ }^{\mathrm{E} 65}$ & 1998 & Case series & INVOS & Biventricular repair & 18 & $\begin{array}{l}\text { Identify periods of cerebral } \\
\text { oxygen supply and demand } \\
\text { mismatch using NIRS. }\end{array}$ & $\begin{array}{l}\mathrm{rScO}_{2} \text { decreased by }>15 \% \text { in } 10 / \\
18 \text { patients before cannulation } \\
\text { with cardiac manipulation. } \\
\mathrm{rScO} 2 \text { increases with the } \\
\text { institution of } \mathrm{CPB} \text { and decays } \\
\text { at } 0.25 \% / \mathrm{min} \text { at }<20^{\circ} \mathrm{C} \\
\text { and } 2 \% / \mathrm{min} \text { at }>20^{\circ} \mathrm{C} \text {. } \\
\mathrm{rScO} \mathrm{O}_{2} \text { varied inversely with } \\
\text { the rate of cooling } \\
(P=.04) \text {. }\end{array}$ \\
\hline Austin et $\mathrm{al}^{18}$ & 1997 & Retrospective & INVOS & $\mathrm{CHD}$ repair with $\mathrm{CPB}$ & 250 & $\begin{array}{l}\text { Examine the potential benefit of } \\
\text { interventions based on intraop } \\
\text { neurophysiologic monitoring } \\
\text { (TCD, EEG, NIRS) in } \\
\text { decreasing postop neurologic } \\
\text { complications and length of } \\
\text { hospital stay. }\end{array}$ & $\begin{array}{l}\text { Of patients with neurologic } \\
\text { changes, significantly more } \\
\text { had noteworthy intraop } \\
\text { changes that were not } \\
\text { intervened on }(P=.003) \text { with } \\
\text { significantly fewer of these } \\
\text { patients discharged from the } \\
\text { hospital within } 1 \text { week } \\
(P<.05) \text {. }\end{array}$ \\
\hline Chow et al ${ }^{\mathrm{E} 66}$ & 1997 & Case series & NIRO & $\begin{array}{r}\text { Noncyanotic } \mathrm{CHD} \\
\text { repair with } \mathrm{CPB}\end{array}$ & 14 & $\begin{array}{l}\text { Explore the relation between } \\
\text { arterial oxygen tension and } \\
\text { CBF during CPB. }\end{array}$ & $\begin{array}{l}\text { No relation between arterial } \\
\text { oxygen tension and CBF. CBF } \\
\text { is associated with CPB flow } \\
\text { rate (decreases } 4.2 \text { fold per } 1 / \\
\left.\mathrm{m}^{2} / \mathrm{min}\right) \text {. }\end{array}$ \\
\hline Van Bel et al ${ }^{\mathrm{E} 67}$ & 1996 & Case series & Radiometer & $\begin{array}{l}\text { Neonatal and infant } \\
\text { CHD repair with CPB }\end{array}$ & 12 & $\begin{array}{l}\text { Investigate the changes in cerebral } \\
\text { hemodynamics and } \\
\text { oxygenation during DHCA. }\end{array}$ & $\begin{array}{l}\text { CBV decreased significantly with } \\
\text { cooling and increased } \\
\text { significantly with rewarming } \\
(P<.001) . \mathrm{CBV} \text { did not change } \\
\text { with pump flow rate or } \\
\text { MAP. }\end{array}$ \\
\hline Fallon et al ${ }^{\mathrm{E} 68}$ & 1994 & Case series & NIRO & $\begin{array}{l}\text { Elective } \mathrm{CHD} \text { repair } \\
\text { with } \mathrm{CPB}\end{array}$ & 19 & $\begin{array}{l}\text { Measure the change in } \mathrm{CBV} \\
\text { associated with changing } \mathrm{PaCO}_{2} \\
\text { (CBVR) under anesthesia and } \\
\text { during hypothermic } \mathrm{CPB} \text {. }\end{array}$ & $\begin{array}{l}\mathrm{CBVR} \text { is preserved under } \\
\text { anesthesia and hypothermic } \\
\mathrm{CPB} \text {. The relationship } \\
\text { between } \mathrm{CBV} \text { and } \mathrm{PaCO}_{2} \text { is } \\
\text { linear. }\end{array}$ \\
\hline
\end{tabular}




\begin{tabular}{|c|c|c|c|c|c|c|c|}
\hline Author & Year & Study design* & Device & Patient population & Total number & Primary end point & Results \\
\hline Skov and Greisen ${ }^{\text {E69 }}$ & 1994 & Case series & Radiometer & $\begin{array}{l}\text { Biventricular cyanotic } \\
\qquad \begin{array}{l}(\mathrm{n}=5) \text { and noncyanotic } \\
(\mathrm{n}=9) \text { CHD repair } \\
\text { with CPB }\end{array}\end{array}$ & 14 & $\begin{array}{l}\text { Examine the changes in cerebral } \\
\text { cytaa }_{3} \text { during induction of } \\
\mathrm{CPB} \text {. }\end{array}$ & $\begin{array}{l}\text { In cyanotic patients, the total } \mathrm{Hgb} \\
\text { decreased rapidly and then } \\
\text { reached a plateau, Cytaa } \\
\text { decreased and oxyHgb index } \\
\text { increased. There were no } \\
\text { significant changes in the } \\
\text { noncyanotic patients. The } \\
\text { magnitude of the change in } \\
\text { Cytaa } 3 \text { was associated with the } \\
\text { magnitude of change in total } \\
\text { Hgb }(P<.0001) \text {. Signal } \\
\text { noise analysis raised concern } \\
\text { about the validity of the } \\
\text { results. }\end{array}$ \\
\hline Fallon et $\mathrm{al}^{\mathrm{E} 70}$ & 1993 & Case series & NIRO & Repair of CHD with CPB & 13 & $\begin{array}{l}\text { Use of NIRS to monitor CBF, } \\
\text { CBV, and CBVR. }\end{array}$ & $\begin{array}{l}\text { CBVR significantly decreased } \\
\text { during hypothermic }\left(25^{\circ} \mathrm{C}\right) \\
\text { bypass. }\end{array}$ \\
\hline \multicolumn{8}{|c|}{ Intraoperative combined with preoperative/postoperative monitoring } \\
\hline McQuillen et $\mathrm{al}^{21}$ & 2007 & Case series & NIRO & $\begin{array}{l}\text { Patients with CHD, preop/postop } \\
\text { MRI and intraop NIRS }\end{array}$ & 16 & $\begin{array}{l}\text { Define the risk factors for preop } \\
\text { and postop brain injuries and } \\
\text { association with functional } \\
\text { cardiac anatomic groups } \\
\text { (intraop NIRS was a secondary } \\
\text { analysis). }\end{array}$ & $\begin{array}{l}\text { TOI significantly decreased } \\
\text { during aortic XC in patients } \\
\text { with positive postop MRIs } \\
(P=.008)\end{array}$ \\
\hline Dent et $\mathrm{al}^{19}$ & 2006 & Case series & INVOS & $\begin{array}{l}\text { Norwood procedure with RLFP, } \\
\text { preop/postop MRI, preop/ } \\
\text { intraop/postop NIRS }\end{array}$ & 22 & $\begin{array}{l}\text { Preop and postop MRI findings } \\
\text { in neonates undergoing } \\
\text { a Norwood procedure with } \\
\text { RLFP. }\end{array}$ & $\begin{array}{l}\text { Prolonged low postop } \mathrm{rScO}_{2} \\
\quad(<45 \% \text { for }>180 \text { minutes }) \text { was } \\
\text { associated with new or } \\
\text { worsening lesions }(P=.029) \\
\text { with a positive predictive value } \\
\text { of } 90 \% \text { for positive MRI } \\
\text { findings. }\end{array}$ \\
\hline Toet et $\mathrm{al}^{17}$ & 2005 & Case series & INVOS & $\begin{array}{l}\text { Transposition of the great arteries } \\
\text { repaired with DHCA, preop/ } \\
\text { intraop/postop NIRS }\end{array}$ & 20 & $\begin{array}{l}\text { Monitoring NIRS before, during, } \\
\text { and after arterial switch } \\
\text { operation to evaluate its } \\
\text { relation to neurodevelopmental } \\
\text { outcomes. }\end{array}$ & $\begin{array}{l}\text { Recovery time for the EEG did not } \\
\text { correlate with normalization of } \\
\text { the } \mathrm{rScO}_{2} \text {. Complete recovery } \\
\text { of the } \mathrm{rScO}_{2} \text { takes } 6-72 \text { hours } \\
\text { postop. Preop decrease in } \mathrm{rScO}_{2} \\
\text { tended to correlate with } \\
\text { decreased Bayley score but was } \\
\text { not significant. }\end{array}$ \\
\hline
\end{tabular}




\begin{tabular}{|c|c|c|c|c|c|c|c|}
\hline Author & Year & Study design* & Device & Patient population & Total number & Primary end point & Results \\
\hline \multicolumn{8}{|c|}{ Monitoring technique } \\
\hline Roberts et al ${ }^{\mathrm{E} 71}$ & 1998 & Case series & NIRO & Repair of CHD with CPB & 19 & $\begin{array}{l}\text { Describe a novel method to } \\
\text { measure CBF using } \\
\text { indocyanine green tracer with } \\
\text { NIRS. }\end{array}$ & $\begin{array}{l}11 \% \text { variation between } \\
\text { measurements within } \\
\text { individual patients, } 73 \% \text { of the } \\
\text { variability was accounted for } \\
\text { by pump flow and temperature }\end{array}$ \\
\hline
\end{tabular}

\begin{abstract}
$A S D$, Atrial septal defect; $C A$, circulatory arrest; $C B F$, cerebral blood flow; $C B F V$, cerebral blood flow velocity; $C B V$, cerebral blood volume; $C B V I$, cerebral blood volume index; $C H D$, congenital heart disease; $C M R O_{2}$, cerebral metabolism; $C P B$, cardiopulmonary bypass; $D H C A$, deep hypothermic circulatory arrest; $E E G$, electroencephalography; $F O E$, fractional oxygen extraction; $H c t$, hematocrit; $M A P$, mean arterial pressure; $M R I$, magnetic resonance ₹ imaging; $N I R S$, near-infrared spectroscopy; $o x y H g b$, oxyhemoglobin; $R L F P$, regional low flow perfusion; $r S O_{2}$, regional oxygen saturation; $S P C C$, systemic-pulmonary collateral circulation; $T C D$, transcranial Doppler; $T O I$, tissue oxygenation index; VSD, ventricular septal defect; $X C$, crossclamp. *Evidence Based Medicine Levels of Evidence: Level 1, systematic review of randomized controlled trials (RCTs), individual RCTs; level 2, systematic review of
\end{abstract}

है 


\begin{tabular}{crlll}
\hline \multicolumn{1}{c}{ Author } & Year & Study design* & Device & Patient populatio \\
\hline $\begin{array}{l}\text { Preoperative ICU monitoring } \\
\text { Takami et } \mathrm{al}^{24}\end{array}$ & 2005 & Preop-postop & NIRO & $\begin{array}{c}\text { CHD patients with } \\
\text { increased pulmonary } \\
\text { blood flow }\end{array}$ \\
Ramamoorthy et al ${ }^{25}$ & 2002 & $\begin{array}{c}\text { Randomized } \\
\text { crossover } \\
\text { observational }\end{array}$ & NIM-prototype & Single ventricle neonates \\
& & &
\end{tabular}

\begin{tabular}{|c|c|}
\hline Total number & Primary end point \\
\hline 8 & $\begin{array}{l}\text { Evaluate serial changes in } \\
\text { oxygenation state in the head } \\
\text { and body in patients with } \\
\text { increased pulmonary blood } \\
\text { flow. }\end{array}$ \\
\hline 15 & $\begin{array}{l}\text { Evaluate changes in } \mathrm{rScO}_{2} \text { with } \\
\text { inspired } 17 \% \mathrm{FIO}_{2} \text { or } 3 \% \mathrm{CO}\end{array}$ \\
\hline $\begin{array}{l}\text { 110: } 91 \text { with CHD, } \\
19 \text { normal }\end{array}$ & $\begin{array}{l}\text { Correlation of } \mathrm{rScO}_{2} \text { and } \mathrm{CEO}_{2} \\
\text { between } \mathrm{CHD} \text { patients and } \\
\text { normals }\end{array}$ \\
\hline
\end{tabular}

\section{Postoperative ICU monitoring}

\begin{tabular}{|c|c|c|c|c|}
\hline McQuillen et al ${ }^{26}$ & 2007 & Case series & INVOS & \\
\hline
\end{tabular}

Results

With decreased $\mathrm{SaO}_{2}$ after the initiation of hypoxia, cerebral and brachial oxyHgb decreased with an increase in deoxyHgb

Significant increase in $\mathrm{rScO}_{2}$ and MAP with $3 \% \mathrm{CO}_{2}$, no change in $\mathrm{rScO}_{2}$ or MAP with $17 \%$ $\mathrm{FIO}_{2}$

$\mathrm{rScO}_{2}$ was significantly decreased in patients with PDA, TOF,

HLHS, PA, SV with shunt, and BDG but was the same for

VSD, $\mathrm{CoA}$, and Fontan. $\mathrm{CEO}_{2}$ was significantly increased for PDA and HLHS. $\mathrm{SaO}_{2}$ was correlated with $\mathrm{rScO}_{2}$ but was not a good substitute $\left(R^{2}=.4\right)$

Relationship between changes in $\mathrm{rScO}_{2}$ with changes in regional flank $\mathrm{So}_{2}$ and central $\mathrm{SvO}_{2}$. Monitored for 24 hours.

Central $\mathrm{SvO}_{2}$ was correlated with $\mathrm{rScO}_{2}$ and flank $\mathrm{rSO}_{2}$ with wide limits of agreement precluding interchangeability. Changes in $\mathrm{PaCO}_{2}$ and MAP were

associated with changes in $\mathrm{rScO}_{2}$ but not flank $\mathrm{rSO}_{2}$ or $\mathrm{SvO}_{2}$. Changes in $\mathrm{SaO}_{2}$ were associated with $\mathrm{SvO}_{2}$ but not $\mathrm{rSCO}_{2}$.

(1) Increased $\mathrm{pH}$, decreased $\mathrm{PCO}_{2}$, Response of $\mathrm{rScO}_{2}$ to (1) hyperventilation with increased $\mathrm{TV}$, (2) hyperventilation with increased RR, (3)

hypoventilation with decreased RR. Monitoring for 4 hours.

and decreased $\mathrm{rScO}_{2}$; (2) same

as 1; (3) no change in $\mathrm{pH}$,

increased $\mathrm{PCO}_{2}$, and increased

$\mathrm{rScO}_{2}$. Hyperventilation should be avoided in patients with

BDG due to potential decrease in $\mathrm{rScO}_{2}$. 


\begin{tabular}{|c|c|c|c|c|c|c|c|}
\hline Author & Year & Study design* & Device & Patient population & Total number & Primary end point & Results \\
\hline Nagdyman et $\mathrm{al}^{30}$ & 2006 & Case series & NIRO & $\begin{array}{l}\text { Elevated pulmonary } \\
\text { vascular resistance } \\
\text { after CPB }\end{array}$ & 13 & $\begin{array}{l}\text { Examine alterations in cerebral } \\
\text { oxygenation in children treated } \\
\text { with increasing doses of } \\
\text { sildenafil for elevated } \\
\text { pulmonary vascular resistance. } \\
\text { Monitored for } 1 \text { hour. }\end{array}$ & $\begin{array}{l}\text { TOI increased significantly after } \\
\text { the first two doses but quickly } \\
\text { returned to baseline }(P=.01) \\
\text { no change with the third dose. } \\
\text { There was no correlation } \\
\text { between cardiac index and TOI }\end{array}$ \\
\hline Li et $\mathrm{al}^{27}$ & 2006 & Case series & INVOS & Postop Norwood pateints & 11 & $\begin{array}{l}\text { Determine if NIRS cerebral and } \\
\text { splanchnic monitoring } \\
\text { accurately reflects systemic } \\
\text { oxygen delivery when } \\
\text { compared with direct } \\
\text { measurements. Monitored for } \\
72 \text { hours. }\end{array}$ & $\begin{array}{l}\mathrm{rScO}_{2} \text { correlates with } \mathrm{SaO}_{2} \text { and } \\
\mathrm{PaO}_{2}(P<.0001) \text { with large } \\
\text { interindividual variation, } \mathrm{rScO}_{2} \\
\text { correlates with } \mathrm{SvO}_{2}(P< \\
.0001) \text { with no interindividual } \\
\text { variation. Overall, large } \\
\text { interindividual variablity and } \\
\text { intraindividual temporal } \\
\text { variablity. }\end{array}$ \\
\hline Bassan et $\mathrm{al}^{29}$ & 2005 & Case series & NIRO & Postop CHD patients & 43 & $\begin{array}{l}\text { Correlation of NIRS parameters } \\
\text { (HbD = deoxyHgb-oxyHgb) } \\
\text { with CBFV by TCD; identify } \\
\text { pressure-passive cerebral } \\
\text { perfusion by simultaneous } \\
\text { measurements of } \mathrm{HbD} \text { and } \\
\mathrm{MAP} \text {; and associate higher } \\
\mathrm{CO}_{2} \text { levels with pressure- } \\
\text { passive cerebral perfusion. } \\
\text { Measurements at } 6 \text { and } 20 \\
\text { hours postop. }\end{array}$ & $\begin{array}{l}\text { Significant relationship between } \\
\text { change in } \mathrm{CBFV} \text { and change in } \\
\mathrm{HbD}(P<.0001) \text {, also with } \\
\text { change in oxyHgb }(P<.001) \text {. } \\
13 \% \text { of patients had disturbed } \\
\text { cerebral pressure } \\
\text { autoregulation at } 6 \text { hours that } \\
\text { persisted at } 18 \text { hours, high end } \\
\text { tidal } \mathrm{CO}_{2} \text { was correlated with } \\
\text { pressure passive rather than } \\
\text { autoregulated cerebral } \\
\text { perfusion }(P<.001)\end{array}$ \\
\hline Tortoriello et $\mathrm{al}^{31}$ & 2005 & Case series & INVOS & $\begin{array}{l}\text { Elective postop } \\
\text { CHD patients }\end{array}$ & 20 & $\begin{array}{l}\text { Compare } \mathrm{rScO}_{2} \text { with } \mathrm{SvO}_{2} \\
\text { (oximetry) after pediatric } \\
\text { cardiac surgery. Single } \\
\text { measurement } 6 \text { hours postop. }\end{array}$ & $\begin{array}{l}\mathrm{rScO}_{2} \text { correlated with } \mathrm{SvO}_{2}(P< \\
.001) \text {. There was low } \\
\text { intrasubject variation with } \\
\text { significant intersubject } \\
\text { variation; therefore cannot } \\
\text { predict absolute values but can } \\
\text { follow trends. }\end{array}$ \\
\hline Nagdyman et $\mathrm{al}^{32}$ & 2004 & Case series & NIRO & Postop CHD patients & 43 & $\begin{array}{l}\text { Determine the relationship } \\
\text { between } \mathrm{TOI} \text { as a value for } \\
\text { regional } \mathrm{rSco}_{2} \text { and global } \mathrm{SvO}_{2} \\
\text { (right atrial saturation via } \\
\text { central line). Single } \\
\text { measurement } 2 \text { to } 3 \text { hours } \\
\text { postop. }\end{array}$ & $\begin{array}{l}\text { TOI correlated with } \mathrm{SvO}_{2}(P< \\
.001) . \mathrm{PaO}_{2}(P=.031), \mathrm{SaO}_{2} \\
(P=.027), \mathrm{SBP}(P=.035) \\
\text { and } \mathrm{MAP}(P=.042) . \text { There } \\
\text { was no correlation with } \mathrm{PaCO}_{2}, \\
\text { heart rate, and hemoglobin. }\end{array}$ \\
\hline
\end{tabular}




\begin{tabular}{|c|c|c|c|c|c|c|c|}
\hline Author & Year & Study design* & Device & Patient population & Total number & Primary end point & Results \\
\hline \multicolumn{8}{|c|}{ Postoperative circulatory assist device monitoring } \\
\hline Giacomuzzi et al $^{33}$ & 2005 & Case series & INVOS & $\begin{array}{l}\text { HLHS with postop circulatory } \\
\text { support }\end{array}$ & 5 & $\begin{array}{l}\mathrm{rScO}_{2} \text { on circulatory support after } \\
\mathrm{SV} \text { repair }\end{array}$ & $\begin{array}{l}\mathrm{rScO}_{2} \text { levels dropped significantly } \\
\text { after separation from } \mathrm{CPB} \text { and } \\
\text { remained } 20 \% \text { below baseline } \\
\text { for } 24 \text { hours and did not } \\
\text { normalize until } 48 \text { hours } \\
\text { despite stable } \mathrm{SvO}_{2}, \mathrm{MAP} \text {, and } \\
\text { decreasing lactates. }\end{array}$ \\
\hline \multicolumn{8}{|c|}{$\begin{array}{l}B D G \text {, Bidirectional Glenn; } C B F V \text {, cerebral blood flow velocity; } C E O_{2} \text {, cerebral } \mathrm{O}_{2} \text { extraction; } C H D \text {, congenital heart disease; } C o A \text {, coarctation of the aorta; } C P B \text {, cardiopulmonary bypass; } F I_{2} \text {, inspired oxygen fraction; } I C U \text {, intensive } \\
\text { care unit; } H L H S \text {, hypoplastic left heart syndrome; } M A P \text {, mean arterial pressure; } N I R S \text {, near-infrared spectroscopy; } P A \text {, pulmonary atresia; } P D A \text {, patent ductus arteriosus; } R R \text {, respiratory rate; } r S c O_{2} \text {, regional cerebral oxygen saturation; } \\
S B P \text {, systemic blood pressure; } S V \text {, single ventricle; } T C D \text {, transcranial Doppler; } T O F \text {, tetralogy of Fallot; } T O I \text {, tissue oxygenation index; } T V \text {, tidal volume; } V S D \text {, ventricular septal defect. *Evidence Based Medicine Levels of Evidence: } \\
\text { Level l, systematic review of randomized controlled trials (RCTs), individual RCTs; level } 2 \text {, systematic review of cohort studies, individual cohort studies; level } 3 \text {, individual case control studies; level } 4 \text {, case series; level } 5 \text {, expert } \\
\text { opinion. }\end{array}$} \\
\hline
\end{tabular}


TABLE E3. NIRS monitoring in the catheterization laboratory

\begin{tabular}{|c|c|c|c|c|c|c|c|}
\hline Author & Year & Study design* & Device & Patient population & Total number & Primary end point & Results \\
\hline Bhutta et $\mathrm{al}^{34}$ & 2007 & Case series & INVOS & OHT annual biopsy & 29 & $\begin{array}{l}\text { Correlation of } \mathrm{rScO}_{2} \text { with IVC, } \\
\mathrm{SVC} \text {, and } \mathrm{PA} \mathrm{SaO}_{2} \text { on RA and } \\
100 \%\end{array}$ & $\begin{array}{l}\mathrm{rScO}_{2} \text { correlates with } \mathrm{SVC} \text { and } \mathrm{PA} \\
\mathrm{SaO}_{2} \text { on RA and } 100 \%\end{array}$ \\
\hline Kirshbom et $\mathrm{al}^{38}$ & 2007 & Case series & INVOS & $\begin{array}{l}\text { Elective cardiac } \\
\text { catheterization in } \\
\text { single ventricle patients }\end{array}$ & 20 & $\begin{array}{l}\text { Determine the best non-invasive } \\
\text { predictor of } \mathrm{SVC} \mathrm{SvO}_{2} \text { as } \\
\text { a marker of adequacy of } \\
\text { systemic oxygen delivery. }\end{array}$ & $\begin{array}{l}\text { NIRS was a significant } \\
\text { independent predictor of SVC } \\
\mathrm{SvO}_{2}(P=.000)\end{array}$ \\
\hline Levy et $\mathrm{al}^{35}$ & 2005 & Case series & $\begin{array}{r}\text { Inspectra Tissue } \\
\text { Spectrometer }\end{array}$ & $\begin{array}{l}\text { Elective cardiac } \\
\text { catheterization }\end{array}$ & $\begin{array}{l}98 \text { (50\% with } \\
\text { intracardiac mixing) }\end{array}$ & $\begin{array}{l}\text { Evaluate tissues saturation (NIRS- } \\
\text { deltoid) as a measure of } \mathrm{SvO}_{2}\end{array}$ & $\begin{array}{l}\text { No correlation between tissue } \\
\text { saturation and } \mathrm{SvO}_{2}\end{array}$ \\
\hline Nagdyman et $\mathrm{al}^{36}$ & 2005 & Case series & NIRO & $\begin{array}{l}\text { Elective cardiac } \\
\text { catheterization }\end{array}$ & 60 & $\begin{array}{l}\text { Correlation between tissue } \\
\text { oxygenation index (TOI) with } \\
\text { jugular } \mathrm{SvO}_{2}\left(\mathrm{SjO}_{2}\right)\end{array}$ & $\begin{array}{l}\mathrm{SjO}_{2} \text { does correlates with TOI with } \\
\text { poor sensitivity of spatially } \\
\text { resolved spectroscopy }\end{array}$ \\
\hline de Vries et $\mathrm{al}^{40}$ & 2000 & Case series & INVOS & Balloon dilation & $\begin{array}{l}11 \text { (I: } 6 \text { no intracardiac } \\
\text { shunt, II: } 5 \text { with } \\
\text { intracardiac shunt) }\end{array}$ & $\begin{array}{l}\text { Changes in cerebral } \\
\text { hemodynamics (TCD) and } \\
\text { oxygen metabolism (NIRS) } \\
\text { during balloon dilation }\end{array}$ & $\begin{array}{l}\text { With balloon dilation, significant } \\
\text { decrease in velocity in the } \\
\mathrm{MCA} \text { with no change in } \mathrm{rScO}_{2} \\
\text { group I, significant decrease in } \\
\mathrm{rScO}_{2} \text { with no change in } \\
\text { velocity in the MCA group II. } \\
\text { Longer inflation time correlated } \\
\text { with longer time to recovery }\end{array}$ \\
\hline Watzman et al ${ }^{39}$ & 2000 & Case series & NIM-prototype & $\begin{array}{l}\text { Elective cardiac } \\
\text { catheterization }\end{array}$ & 20 & $\begin{array}{c}\text { Correlation of } \mathrm{SaO}_{2}, \mathrm{rScO}_{2}, \text { an } \mathrm{Sjo}_{2} \\
\text { with normocapnia/ } / \mathrm{FIO}_{2} 21 \%, \\
\text { normocapnia/ } / \mathrm{FIO}_{2} 100 \%, \\
\text { hypocapnia/FIO } 2 \text {, } 21 \%\end{array}$ & $\begin{array}{l}\mathrm{rScO}_{2} \text { correlates with } \mathrm{SaO}_{2} \text { and } \\
\mathrm{Sjo}_{2} \text {. The arterial to venous } \\
\text { ratio for } \mathrm{rScO}_{2} \text { is consistent } \\
\text { within patients but varies } \\
\text { significantly between patients }\end{array}$ \\
\hline Daubeney et al ${ }^{37}$ & 1996 & Case series & INVOS & $\begin{array}{l}\text { Pediatric CHD patients } \\
\text { in the cath lab (29) and } \\
\text { during cardiac surgery (11) }\end{array}$ & 40 & $\begin{array}{l}\text { Determine if } \mathrm{rScO}_{2} \text { reflects jugular } \\
\text { bulb venous saturations. }\end{array}$ & $\begin{array}{l}\text { Correlation between } \mathrm{rScO}_{2} \text { and } \\
\text { jugular bulb } \mathrm{SvO}_{2} \text { was } 0.69 \\
(P<.0001) \text { with decreased } \\
\text { reliability at extremes. }\end{array}$ \\
\hline
\end{tabular}

$\overline{C H D}$, Congenital heart disease; $\mathrm{FIO}_{2}$, inspired oxygen fraction; $I V C$, inferior vena cava; $M C A$, main cerebral artery; $N I R S$, near-infrared spectroscopy; $O H T$, orthotopic heart transplantation; $P A$, pulmonary atresia; $R A$, radial artery; $r \mathrm{SCO}_{2}$, regional cerebral oxygen saturation; $\mathrm{Sjo}_{2}$, jugular $\mathrm{Svo}_{2}$; $\mathrm{SVC}$, superior vena cava; $T C D$, transcranial Doppler; $T O I$, tissue oxygenation index. *Evidence Based Medicine Levels of Evidence: Level l, systematic review of randomized controlled trials $(R C T s)$, individual RCTs; level 2, systematic review of cohort studies, individual cohort studies; level 3, individual case control studies; level 4, case series; level 5, expert opinion. 